\title{
China syndrome?
}

In his contribution to this issue of ET, 'Learners and users of English in China,' Jian Yang notes:

'In the now worldwide discussion about English in China, English in Asia, and World Englishes, China's huge English-knowing population is often cited as evidence in support of both the globalization of the language and, in effect, its nativization in the world's most populous country. According to various estimates, the number of Chinese able to use English is estimated at somewhere between 200 and 350 million: cf. Bolton, 2002, 2003; Kachru, 1997c; Kirkpatrick \& Xu, 2002; McArthur, 2002, 2003; Zhao \& Campbell, 1995. Notably, whereas the word user is applied to those who use English in India, Singapore, and other Outer Circle and Expanding Circle countries, it sometimes teams up with the word learner when reference is made to the English in China, often in the same paragraph or article (cf. McArthur, 2003) or the same chapter in a book (cf. McArthur, 2002). It is thus clear that in such contexts a learner and a user are seen to be synonymous or interchangeable, and the referents of the two words ("someone who learns English" and "someone who knows and uses the language") are given the same status.'

I must plead guilty to at times conflating the labels learners and users (which may well overlap in practical terms but are not in essence the same). However I hope I have never argued (explicitly or implicitly) that English is being nativized in China. Even in terms of India, where the language has been in use since the eighteenth century, it is risky to assert that it is indigenous there, apart from one small community, the Anglo-Indians (who are Eurasians of Indian and British provenance), regardless of how widely it is used as a social vehicle. English is however further along a cline towards indigenization in India than in China, a state of affairs that is likely to continue. What is remarkable, though, is that China does now have English as its 'window on the world', much as India has done for generations - and that middle-class Chinese parents want access to English for their children.

The inter-impact of language complexes like Chinese, HindiUrdu, Arabic, Russian, Spanish, and English is one of the foremost features of our time. Some of these complexes are widely distributed, as with English in the world, Spanish in the Americas, and Arabic from Morocco to the Gulf, whereas others are predominant regionally, as with Hindi-Urdu in India and Pakistan, and Russian from the Baltic to the northern Pacific. Inevitably they interact with and influence other languages, but just what will happen linguistically in and around China is at present anybody's guess.

\section{Tom McArthur}

The editorial policy of English Today is to provide a focus or forum for all sorts of news and opinion from around the world. The points of view of individual writers are as a consequence their own, and do not reflect the opinion of the editorial board. In addition, wherever feasible, ET generally leaves unchanged the orthography (normally British or American) and the usage of individual contributors, although the editorial style of the journal itself is that of Cambridge University Press.
English Today (ISSN 0266-0784) is published quarterly by Cambridge University Press, The Edinburgh Building, Shaftesbury Road, Cambridge CB2 2RU, UK / Cambridge University Press, 40 West 20th Street, New York, N.Y. 10011-4211.

(c) Cambridge University Press 2006. No contents may be reproduced by any means without the permission of Cambridge University Press.

Subscriptions: The 2006 subscription price (excluding VAT) for four issues for libraries and institutions, which includes print and electronic access, is f98 outside of North America; $f 34$ for individuals; $f 25$ for students and the retired. The electronic-only price available to institutional subscribers is f86. Prices include delivery by air where appropriate. Apply to Jane Crossland at the above address.

Advertising Sales: write to the Advertising Promoter at the above address. Email:

journals_marketing@cup.cam.ac.uk

\section{USA, CANADA AND MEXICO:}

Subscriptions: The 2006 subscription price (excluding VAT) for four issues for libraries and institutions, which includes print and electronic access, is \$164 in USA, Canada and Mexico; \$54 for individuals; $\$ 39$ for students and the retired. The electronic-only price available to institutional subscribers is $\$ 140$. Apply to Marianne Headrick at Cambridge University Press,

40 West 20th Street, New York, N.Y. 10011-4211.

Advertising Sales: write to the Advertising Coordinator at the above address.

Periodicals postage paid at New York, NY and at additional mailing offices.

POSTMASTER: Send address changes to English Today, Cambridge University Press, 100 Brook Hill Drive, West Nyack, N.Y. 10994-2133.

Japanese prices for institutions are available from Kinokuniya Company Ltd, P.O. Box 55, Chitose, Tokyo 156 , Japan.

\section{Contacting the Editor: Email Dr Tom} McArthur at <Scotsway@aol.com> or write to him at 22-23 Ventress Farm Court, Cherry Hinton Road, Cambridge CB1 8HD, UK. Tel 01223245934.

Internet access This journal is included in the Cambridge Journals Online service which can be found at http://uk.cambridge.org/journals. For further information on other Press titles access http://uk.cambridge.org.

Designed and typeset by Peter Ducker. Printed in the United Kingdom at the University Press, Cambridge. 